\title{
Management of socio-economic systems in Ukraine: European integration paradigm
}

\author{
Larisa Yankovska ${ }^{1}$
}

Received: 2021-03-11

Accepted: 2021-04-08

DOI: http://doi.org/10.46489/gpj.2021-1-1-3

\begin{abstract}
The theory and methodology of management of socio-economic systems are constantly evolving, reflecting the objective processes of departure from the Soviet, postSoviet and transitional paradigms of Ukrainian society. The next step is no less complex reform due to the integration of Ukraine into the European economic, social, legal, civilisational space. Today, Ukraine's European integration has become a national idea, a strategic vector of geopolitical development, which is a criterion for the success or failure of reforms in all areas of national economic governance. In this article, we examined the change in the socio-economic paradigm in connection with Ukraine's European integration development priority. We analysed the conditions for forming the European integration paradigm, explored the critical European values and the content of modern management of socio-economic systems. We have described approaches to assessing the effectiveness of socio-economic systems management at the national and regional levels. Considering the directions of European integration processes, we concluded that the European integration paradigm should become a methodological guideline for reforms in the management of socioeconomic systems.
\end{abstract}

Keywords: management of socio-economic systems, European integration, system, sustainable development, paradigm.

\footnotetext{
1 Larisa Yankovska, DSc, Professor, Honored Worker of Education of Ukraine, Chancellor, Lviv university of business and law, Kulparkivska, 99, 79021 Lviv, Ukraine, e-mail: larisalubp@gmail.com, ORCID: http://orcid.org/0000-0003-1855-0169
} 


\section{ВСТУП}

Теорія та методологія управління соціально-економічними системами безупинно розвивається, відбиваючи об'єктивні процеси відходу від радянської, пострадянської і перехідної парадигми становлення українського суспільства. На черзі не менш складна реформа, зумовлена інтеграцією України у європейський економічний, соціальний, правовий, цивілізаційний простір. Європейська інтеграція України на сьогоднішній день стала національною ідеєю, стратегічним вектором геополітичного розвитку, що $\epsilon$ критерієм успішності чи невдачі реформ у всіх сферах управління національною економікою. Таким чином, актуальною проблемою сучасності $€$ обгрунтування євроінтеграційних чинників, що впливають на управління соціальноекономічними системами в Україні.

у існуючих вітчизняних дослідженнях управління соціальноекономічними системами останні позиціонуються з точки зору перехідної економіки пострадянського періоду. Зі зміною стратегічного бачення розвитку національної економіки, що відбулося після Революції гідності, невирішеною частиною проблеми управління соціально-економічними системами $\epsilon$ врахування окремих євроінтеграційних чинників на різних управлінських рівнях - від держави до регіону. Цьому питанню присвячується дана стаття.

Метою статті $€$ обгрунтування євроінтеграційних чинників, що впливають на трансформацію підходів до управління соціально-економічними системами в Україні.

\section{РЕЗУЛЬТАТИ}

Великим здобутком i першим кроком у напрямі стирання кордонів та відновлення історичної справедливості стало уведення безвізового режиму України з Європейським союзом. Однак, це лише початок тривалого періоду реформ, у більшості своїй болючих, оскільки їх спільною концептуальною основою $\epsilon$ відсторонення від радянського минулого та перехід у якісно новий стан державотворення наближення до європейських стандартів.

Вкрай важливим $\epsilon$ для нас сьогодні не лише декларувати, а й поділяти європейські цінності, серед яких слід наголосити на повазі до демократичних принципів, верховенства права, доброго врядування, прав людини i основоположних свобод, у тому числі прав осіб, які належать до національних меншин, недискримінації осіб, які належать до меншин, i повазі до різноманітності, людської гідності та відданості принципам вільної ринкової економіки, які сприяють участі України в Європейських політиках. Посилення зв'язків між Європейським союзом та Україною базується на досягненні останньою принципів верховенства права, належного врядування, боротьби 3 корупцією, боротьби 3 різними формами транснаціональної організованої злочинності й тероризмом, сприяння сталому розвитку i ефективній багатосторонності.

Політична асоціація та економічна інтеграція України 3 Європейським Союзом залежатиме від прогресу в імплементації Угоди про асоціацію, а також від досягнень України в забезпеченні поваги до спільних цінностей і прогресу в наближенні з ЄС у політичній, економічній та правовій сферах.

Економічному та галузевому співробітництву України $3 \in \mathrm{C}$ присвячено окрему главу у Угоді про асоціацію. Серед основних напрямків співробітництва - енергетика, управління державними фінансами, охорона навколишнього середовища, інфраструктурні питання та багато інших, що можливо узагальнити, як реалізацію довгострокових цілей сталого розвитку. Не менш важливим $\epsilon$ i 
співробітництво у сфері науки та технологій.

Посилення

технологічного наукового Ta співробітництва України з ЄС має на меті як науковий розвиток як такий, так і зміцнення свого наукового потенціалу для вирішення національних та глобальних викликів. Досягнення прогресу в набутті наукових та технологічних знань, важливих для забезпечення сталого економічного розвитку забезпечується шляхом розвитку дослідних потужностей та людського потенціалу. Накопичення та обмін науковою інформацією сприяють підвищенню конкурентоспроможності сторін шляхом розширення можливостей їх економіки щодо набуття та використання знань для комерціалізації нових продуктів та послуг. Від розвитку наукового потенціалу залежить дотримання глобальної відповідальності та зобов'язань у таких сферах, як охорона здоров'я, захист навколишнього середовища, зокрема зміна клімату, та інші глобальні виклики.

Автори Національної доповіді «Соціально-економічний потенціал сталого розвитку України та її регіонів» $(2014,7)$ наголошують, що перехід національного господарства України на модель сталого розвитку значною мірою залежить від наявного потенціалу розширеного відтворення ресурсної бази соціально-економічного піднесення на новій інституціональній і технологічній основі. Досвід передових країн та наслідки структурної i системної перебудови більшості сегментів національного господарства свідчать, що реальні зрушення в напрямі формування передумов сталого розвитку як держави в цілому, так і окремих регіонів можливі лише за умови нарощення не лише виробничого, а й природно-ресурсного, демографічного, науково-технічного, рекреаційного, інформаційного та соціально-культурного потенціалу. Тобто, мова йде про всі складові соціально-економічного потенціалу, а також людський фактор та інституціональні зміни в системі економічних відносин при виборі пріоритетів переходу національного та регіональних господарських комплексів на модель сталого розвитку. Підготовка цієї національної доповіді зумовлена необхідністю врахування численних екзогенних та більшою мірою ендогенних чинників соціальноекономічного потенціалу сталого розвитку у зв'язку з інституціональним закріпленням євроінтеграційних прагнень українського народу.

Щодо визначення поняття соціально-економічної системи можемо навести міркування Т. В. Рудакової (2008), котра відзначає, що соціальноекономічну політику регіону можна визначити як забезпечення життєдіяльності людей на певній території. Задоволення їх життєвих можливостей можливо при двох обставинах: при наявності необхідної сукупності матеріальних та духовних благ та при можливості цими благами користуватися. Названі блага формуються в процесі суспільного виробництва, яке $\epsilon$ основою для створення необхідних життєвих благ, з одного боку, та отриманням доходів від створення цих благ, 3 другого боку. Соціально-економічну систему можна характеризувати як системи, що моделюють господарсько-економічну діяльність у сукупності з регулюванням соціальної сфери суспільства певного регіону.

Е. В. Щепанський (2009) наголошує, що здійснення соціально-економічних реформ в Україні, спрямованих на забезпечення стабільних умов життя та підтримку належного рівня добробуту населення, як і адаптація с промислового виробництва до загальносвітових тенденцій розвитку, пов'язаних із к формуванням 
постіндустріальної

економіки, вимагають посиленої уваги до процесу здійснення структурних перетворень в регіональному господарському комплексі. Саме 3 структурною політикою пов'язаний комплекс специфічних завдань періоду перетворень - від формування сучасного ринкового середовища до подолання екстенсивного типу розвитку країни та іï регіонів, усунення численних деформацій їі структури. Реалізація зазначених цілей вимагає розробки відповідного механізму управління соціально-економічним розвитком. О. Половцев (2010) зазначає, що функціонування соціальноекономічних систем являє собою складний процес, зумовлений великою кількістю різноманітних факторів. На сьогодні дуже незначна частина завдань, що розв'язуються в процесі державного управління, мають аналітичну підтримку у вигляді моделей керованих процесів та систем. Система державного управління, на думку науковця, $€$ переплетінням множини структур та процесів різної природи, кожен 3 яких функціонує у взаємодії та тісній інтеграції з іншими процесами та системами. Прийняття задовільних рішень 3 прогнозованою ефективністю неможливе без аналітичної підтримки та передбачає використання більш-менш формалізованої моделі керованого об'єкта. Модель процесу прийняття рішення в галузі державного управління відображає особливості процедур підготовки та вибору рішень, участь у них адміністрації відповідних рівнів, зв'язок ресурсів та зовнішніх умов із станом керованої соціально-економічної системи та результатами впровадження рішень. 3 цього приводу О. Е. Кац (2012) підкреслює, що державне управління соціально-економічними системами в ринкових умовах неможливе без аналізу дії чинників зовнішньої і внутрішньої середовища, оскільки будь-яка система є відкритою, працюючою в нестабільному ринковому середовищі. Це означає, що система має зв'язок із зовнішнім середовищем, що реалізовується за допомогою взаємного обміну різними ресурсами (природними, матеріальними, технічними, енергетичними, людськими, інформаційними, фінансовими).

В умовах децентралізації все більше повноважень щодо управління соціально-економічними системами відходить на рівень регіонів.

C. М. Юрійчук (2011) з цього приводу відзначає, що на сучасному етапі соціально-економічного розвитку регіонів дослідження регіонального управління $\epsilon$ складною комплексною системою і потребує багатоаспектного підходу 3 застосуванням теорії наукового управління. Науковець підкреслює, що соціально-економічний розвиток регіону - це цілісна система закономірностей, зв'язків і пропорцій здійснення відтворювальних процесів суб'єкта ми господарської діяльності різних форм власності на адміністративно окресленій території.

Як зауважує С. М. Юрійчук (2011), соціально-економічний розвиток регіону, з одного боку, - об'єктивний процес, що відбувається під впливом історичних, географічних, ресурсних, демографічних та інших факторів. 3 другого боку, - це суб'єктивний процес, що здійснюється під впливом управлінських заходів 3 боку регіональної адміністрації адміністрації державного рівня.

На рівні управління соціальноекономічним розвитком систем окремих закладів, установ, підприємств актуальною $є$ проблема напрацювання стратегії розвитку в умовах непередбачуваних подій, передусім кризового характеру. 3 цього приводу 0. P. Савченко (2012) зауважує, що основними властивостями сучасного 
бізнес-середовища,

B

якому

функціонують вітчизняні організації, $\epsilon$ мінливість, невизначеність i нестабільність. Такі умови вимагають від керівників організацій здатності інтуїтивно відчувати проблеми ринкового господарювання, професійно підходити до їх подолання (уникнення, якщо таке можливо, або прийняття шляхом ефективного управління). Для забезпечення останнього керівники повинні мати високопрофесійні навички, вміння та досвід, повинні бути обізнаними 3 чинниками, які притаманні сфері їх господарювання, ситуативними механізмами управління тощо.

Оцінка ефективності управління соціально-економічним розвитком може здійснюватись на основі низки методик. Серед них, О. Е. Кац (2012) пропонує виділяти такі, що пов'язані, перш за все, з контролем реалізації місії і бачення глобальних і базових стратегій. Вирішення цих завдань, зауважує науковець, може бути досягнуте на основі використання таких наукових методів, як діагностичний аналіз, аналіз основних чинників зовнішньої середовища на основі комплексного (соціального, технічного, економічного і політичного, природного) STEP-аналізу для виявлення можливостей і загроз; аналіз сильних і слабких сторін внутрішнього середовища соціальноекономічної системи; спільний матричний аналіз сильних, слабких сторін можливостей і загроз (SWOTаналіз); аналіз стратегічного потенціалу, конкурентних переваг, умов функціонування i привабливості на основі спеціальної розробленої номограми 3 метою виявлення глобальної стратегії для соціальноекономічної системи.

Т. В. Рудакова (2008) наголошує, що глобалізація економіки $\epsilon$ багатогранним процесом, основними рушійними силами якого $є$ технологічний прогрес, розвиток міжнародної інфраструктури, зміни в інформаційній технології та лібералізація торгівлі та міжнародних зв'язків. Ці фактори, як показує практика економічного розвитку усіх країн світу, мають безпосередній вплив на соціальний та економічний розвиток. Перш за все це позначається на зростанні обсягів торгівлі товарами та послугами. Важливим наслідком глобалізації стала інтенсифікація потоків прямих іноземних інвестицій, обсяги яких $\epsilon$ особливо динамічними. Технічні та технологічні зміни, що $\epsilon$ необхідною передумовою розвитку людини, спричиняють трансграничний рух капіталу, виробничих потужностей, товарів та послуг, переміщення робочої сили. Такі процеси викликають зміни в соціальній сфері, що призводить до переміщення та скорочення робочих місць, девальвації традиційних спеціальностей та потреби нової кваліфікації.

He менш важливим $\epsilon$ питання критерію економічної безпеки в управлінні соціально-економічним розвитком на усіх рівнях. 0. Д. Гудзинський та С. М. Судомир (2014) акцентують на тому, що у сучасних умовах здійснення глобалізаційних та інтеграційних процесів ускладнюються економічні зв'язки між суб'єктами діяльності горизонтально вертикального спрямування, скорочується часовий лаг життєвих циклів дій систем і механізмів підтримання підприємницьких структур в стані запрограмованого функціонування згідно за часовими, кількісними і якісними параметрами. Вибір точки проведення змін в соціально - економічних системах $\epsilon$ базовою i методологічною основою забезпечення їх динамічного, стратегічно - конкурентного розвитку та економічної безпеки.

Окремо слід наголосити на значенні європейської інтеграції для галузі освіти в Україні. Співробітництво в галузі освіти, навчання та молодіжної 
політики має на меті покращення взаєморозуміння, активізації міжкультурного діалогу та посилення знань щодо відповідних культур. Найважливішими напрямками євроінтеграційних процесів у сфері вищої освіти $€$ такі, як

а) реформування та модернізації систем вищої освіти;

b) сприяння зближенню у сфері вищої освіти, яке відбувається в рамках Болонського процесу;

c) підвищення якості та важливості вищої освіти;

d) поглиблення співробітництва між вищими навчальними закладами;

е) розширення можливостей вищих навчальних закладів;

f) активізації мобільності студентів та викладачів;

g) увага приділятиметься співробітництву в галузі освіти з метою спрощення доступу до отримання вищої освіти.

\section{ВИСНОВКИ}

Таким чином, на основі проведеного дослідження встановлено, що євроінтеграція України за умов успішного проходження усіх етапів цього процесу, $є$ безумовним чинником процвітання нашої держави. Проте до цього моменту існує безліч викликів в реформуванні управління соціальноекономічними системами різних рівнів, що відкриє для Україні перспективи повноцінного членства у Європейському Союзі.

\section{References}

Hudzynskyi, O. D., \& Sudomyr, S. M. (2014). Ryzyky ta ekonomichna bezpeka sotsialno-ekonomichnykh system. Zbirnyk naukovykh prats Tavriiskoho derzhavnoho ahrotekhnolohichnoho

(ekonomichni nauky), 2.35-37

Kats, O.A. (2012). Derzhavne rehuliuvannia ta kontrol rozvytku i funktsionuvannia sotsialnoekonomichnykh system riznykh rivniv. Upravlinnia proektamy ta rozvytok vyrobnytstva, 3 (43). 114- 117

Libanova, E. M., \& Khvesyk, M. A. (Red.). (2014). Sotsialno-ekonomichnyi potentsial staloho rozvytku Ukrainy ta yii rehioniv: Natsionalna dopovid. DU IEPSR NAN Ukrainy.

Polovtsev, 0. (2010). Metody modeliuvannia dynamiky sotsialnoekonomichnykh system. Visnyk Natsionalnoi akademii derzhavnoho upravlinnia pry Prezydentovi Ukrainy, 1. 105-111

Rudakova, T.V. (2008). Metodolohichni pryntsypy rozghliadu sotsialnoekonomichnoi systemy rehionu $\mathrm{v}$ period transformatsii pidsystem suspilstva. Ekon.mat. modeliuvannia sots.-ekon. system, 13. 186-192.

Savchenko, O. R. (2012). Upravlinnia zminamy $\mathrm{V}$ suchasnykh sotsialnoekonomichnykh systemakh. Aktualni problemy ekonomiky, 3. 19-24

Shchepanskyi, E. V. (2009). Formy ta metody upravlinnia sotsialnoekonomichnym rozvytkom: teoretychnyi aspekt. Universytetski naukovi zapysky, 3. 273-279

Yuriichuk, S. M. (2011). Osoblyvosti upravlinnia sotsialno-ekonomichnym rozvytkom rehioniv $\mathrm{u}$ suchasnykh umovakh. Investytsii: praktyka ta dosvid, 6. 52-53 